\title{
Hair Dyeing and Colorfastness Using Extracts of Blueberry
}

Eun-Suong Seo, Chul-Ho Park ${ }^{*}$

Department of Cosmetology Science, Nambu University, Gwangju, Korea

\author{
*Corresponding authors: Chul-Ho Park, \\ Department of Cosmetology Science, \\ Nambu University, 23 Chumdanjungang-ro, \\ Gwangsan-gu, Gwangju 62271, Korea \\ Tel.: +82629700140 \\ Fax: +82 629700140 \\ Email: chpark@nambu.ac.kr
}

Received March 19, 2017

Revised May 8, 2017

Accepted May 16, 2017

Published September 30, 2017

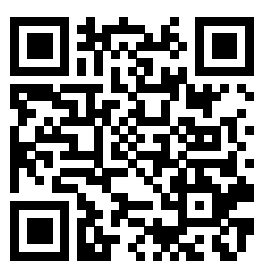

\begin{abstract}
Purpose: The purpose of this study is to examine the possibility of natural hair dyeing using anthocyanin pigments from blueberries. Methods: The hair dyeing and color change of blueberry extracts were measured at the maximum absorption wavelength of anthocyanin by varying dyeing temperature, dyeing time, and $\mathrm{pH}$. Several mordants were used, and the mordanting effects and colorfastness were investigated in accordance with the mordanting method and mordant concentration. Results: The maximum absorption wavelength of anthocyanin in the blueberry extracts was 520 $\mathrm{nm}$. As the dyeing temperature and dyeing time increased, the dye uptake (K/S) increased and lightness $\left(L^{*}\right)$ decreased; the $\mathrm{K} / \mathrm{S}$ were in the 21.639-58.968 range. The most effective condition for hair dyeing using anthocyanin pigments was $40^{\circ} \mathrm{C}$ for $40 \mathrm{~min}$. Anthocyanin pigments are especially sensitive to $\mathrm{pH}$, and $\mathrm{K} / \mathrm{S}$ decreased with increasing $\mathrm{pH}$. It was found that the redness $\left(\mathrm{a}^{*}\right)$ increased in acid and the yellowness $\left(\mathrm{b}^{*}\right)$ increased in alkali. Based on the $\mathrm{K} / \mathrm{S}$ value only, pre-mordanting was effective for $\mathrm{FeSO}_{4}, \mathrm{MgSO}_{4}, \mathrm{MnSO}_{4}, \mathrm{CuSO}_{4}, \mathrm{CH}_{3} \mathrm{COOH}, \mathrm{Co}\left(\mathrm{NO}_{3}\right)_{2}, \mathrm{CaCO}_{3}$, and $\mathrm{Na}_{2} \mathrm{CO}_{3}$, and post-mordanting was effective for AIK $\left(\mathrm{SO}_{4}\right)_{2}$. The changes of $\mathrm{K} / \mathrm{S}$ values at mordant concentrations were 69.665 for $1 \% \mathrm{FeSO}_{4}$ and 59.515 for $5 \%$ and $15 \% \mathrm{CuSO}_{4}$. $\mathrm{AlK}\left(\mathrm{SO}_{4}\right)_{2}$ and $\mathrm{Co}\left(\mathrm{NO}_{3}\right)_{2}$ showed high $\mathrm{K} / \mathrm{S}$ changes of 66.555 and 63.127 at $20 \%$, respectively. The colorfastness to washing was decreased with repeated shampooing. The K/S was in the 46.333-21.098 range, and the K/S difference was 16.911 after washing. Conclusion: Extracts from blueberries may be useful to be used as a hair dye.
\end{abstract}

Keywords: Blueberry, Dyeing, Anthocyanin, Mordant, Colorfastness

\section{Introduction}

최근 들어 현대 의학의 발전으로 인간의 수명 연장과 삶의 질적 향 상이 이루어짐에 따라 건강한 삶에 대한 중요성과 외모의 아름다움 에 대한 욕구가 증가하게 되었다. 이처럼 나이보다 더 젊고 아름다 워 보이기 위한 욕구는 적은 비용으로도 큰 효과를 기대할 수 있는 모 발 염색에 대한 관심으로 나타나고 있다. 모발 염색 시 가장 많이 사 용하는 영구 염색제에는 $p$-페닐렌디아민( $p$-phenylenediamine, $\mathrm{PPD}), m$-아미노페놀 ( $m$-aminophenol), $o$-아미노페놀 (o-aminophenol) 및 레조시놀(resorcinol) 등의 성분이 포함되 어져 있는데(Lee \& Chang, 2011), 특히 PPD는 피부발진, 습진, 두피에 염증을 유발하여 알레르기성 접촉피부염을 일으키며, 심 할 경우 얼굴 부종과 동통성 타박상이 발생하거나 가려움증, 안구 통증, 시력 손상, 두피질환 및 탈모 등 부작용을 유발한다(Lee \& Park, 2012). 또한 영구 염색 과정에서 큐티클층으로 화학물질의 침투를 위하여 사용하는 $\mathrm{pH}$ 9-10정도의 암모니아 용액은 원하는
색깔을 얻을 수는 있지만 모발 손상을 일으킨다(Lee \& Chang, 2011). 모발의 갈라짐, 끊어짐과 같은 모발 손상이 발생하면 회복 이 불가능하여 이는 잘라냄으로써 제거된다(Chae et al., 2010). 천연 염료는 다양한 색상의 변화를 추구하기가 어렵고 견뢰도 및 재현성이 떨어지는 단점이 있으나, 합성염료에 비해 자연스런 색감과 인체에 독성이 없고 환경오염물질을 적게 배출한다는 장 점으로 인하여 영구 염모제의 대안으로 떠오르고 있다(Ali et al., 2009; Jung et al., 2008). 최근 천연 염료에 대한 연구 가운데 다색성 염료인 안토시아닌(anthocyanin) 색소는 다양한 매염제로 사용될 뿐만 아니라, 매염 조건 및 매염 방법을 선택함으로써 단 일색소로도 다양한 색상을 구현할 수 있어 모발 염색에 적용 가능 하다고 보고되었다(Choi \& Park, 2016; Jang \& Park, 2015).

블루베리(blueberry)는 진달래과(Ericaceae) 산앵두나무속 (Vaccinium)에 속하는 관목성 식물로 전세계적으로 400여종이 있으며, 주로 북미지역에 분포하고 있다(Choi \& Shin, 2015). 북 미에서는 북부 하이부시 블루베리(Vaccinium corymbosum), 로 
우부시 블루베리(Vaccinium angustifolium) 및 래빗아이 블루베 리(Vaccinium ashei) 등 세 종류가 상업적으로 재배되고 있으며 (Westwood, 1993), 우리나라에서는 과실의 품질이 뛰어난 북부 하 이부시 블루베리가 주로 재배되고 있다. 블루베리가 함유하고 있 는 안토시아닌, 플라보노이드(flavonoid), 라이코펜(lycopene)은 항 산화(Choi \& Shin, 2015; Jeong et al., 2008; Lim et al., 2015; Song et al., 2014; Su \& Chien, 2007), 항당뇨(Martineau et al., 2006), 항암(Jang et al., 1997; Lee \& Kang, 2008) 및 시력강화 (Seo \& Ryu, 2012) 효과가 있다고 보고되었다.

블루베리를 이용한 모발 염색 및 매염 효과에 대한 연구는 미흡 한 실정이나, 견직물의 자초 염색 시 합성 타닌(tannin)을 매염제 로 사용한 결과 염색 효과와 견뢰도가 향상된다고 보고되었다(Park et al., 2008). 따라서 본 연구에서는 인체에 유용한 블루베리의 안 토시아닌 색소를 염색 온도, 염색 시간, $\mathrm{pH}$, 매염제 종류, 매염 방 법(선매염, 동시매염, 후매염), 매염제 농도에 따른 모발 염색성 및 견뢰도를 조사하여 모발에 다양한 색상을 구현할 수 있는 염제로서 의 가능성을 알아보고자 하였다.

\section{Methods}

\section{1. 연구 재료}

본 실험에 사용된 블루베리는 냉동제품(Blueberries; Tesco, Chile)으로 구입하였으며, 저온압착방식의 착즙기(HE-DBF04; Hurom, Korea)를 이용하여 추출한 후 염제로 사용하였다. 모발시 료는 18세 버진헤어(virgin hair) 전체 모발 길이 $18 \mathrm{~cm}$ 에서 모근쪽 에서 10-15 cm를 채취하여 실험에 사용하였다. 모발시료의 탈색은 파우더 타입의 1제(Promaster Powder Bleach; Hoyu, Japan)와 $6 \%$ 과산화수소(Pro-oxide; Hoyu)를 2제로 사용하여 1제와 2제를 $1: 1$ 비율로 혼합하여 사용하였다. 실온 $25^{\circ} \mathrm{C}$ 에서 자연 방치 후 30 $\min$ 간격으로 3 회에 걸쳐 명도 10 레벨로 탈색시킨 다음, 탈색이 끝 난 시료는 증류수를 흘려서 수세하고 자연 건조하였다. 탈색된 모 발은 진공 팩에 넣어 보관 후 시험에 사용하였다.

탈색된 모발시료의 상단 부분을 스와치(swatch)로 글루건(glue gun)을 사용하여 한 시료 폭당 $1 \mathrm{~cm}$ 길이로 만들어 염색 온도별 염 색 시간과의 염색성에 15 개, $\mathrm{pH}$ 에 따른 염색성에 8 개, 매염제별 매 염 방법에 따른 매염 효과에 27 개, 매염제 농도에 따른 매염 효과에 20 개, 세정 견뢰도에 3 개를 제작한 후 진공팩에 넣어 암실에 보관 후 사용하였다.

\section{2. 연구 방법}

\section{1) 안토시아닌의 최대흡수파장}

블루베리 염액으로 염색된 모발시료를 분광측색계(JS-555; Color Techno System, Japan)로 400-700 nm 사이에서 $10 \mathrm{~nm}$
간격으로 측정하여 안토시아닌 색소의 최대흡수파장을 결정하였다.

2) 염색 온도 및 염색 시간에 따른 모발 염색 효과

블루베리 추출액 $15 \mathrm{~mL}$ 에 모발시료를 담가 항온수조에서 온 도를 $25,40,60^{\circ} \mathrm{C}$ 로 하고 각각 $10,20,40,60,80 \mathrm{~min}$ 동안 염 색하였다. 염색된 모발은 흐르는 증류수에 수세하여 자연 건조하 였고, 염색 전, 후 모발시료의 색 변화량을 관찰하기 위하여 분 광측색계와 분광측색계 Reader (ver 1.01; Daego, Korea)를 사 용하여 측정하였다. 분광측색계로 안토시아닌의 최대흡수파장에 서 시료의 X, Y, Z 값을 측정하고 $\mathrm{CIE} \mathrm{Lab}$ 색차식을 이용하여 L-value (lightness; 명도), a-value (redness; 적색도), b-value (yellowness; 황색도) 값을 3회 반복 측정하여 평균 값으로 나타내 었다(Shin \& Park, 2014).

$$
\begin{aligned}
& L^{*}=116\left(\frac{Y}{Y_{\mathrm{n}}}\right)^{\frac{1}{3}}-16 \\
& a^{*}=500\left[\left(\frac{X}{X_{\mathrm{n}}}\right)^{\frac{1}{3}}\left(\frac{Y}{Y_{\mathrm{n}}}\right)^{\frac{1}{3}}\right] \\
& b^{*}=200\left[\left(\frac{Y}{Y_{\mathrm{n}}}\right)^{\frac{1}{3}}\left(\frac{Z}{Z_{\mathrm{n}}}\right)^{\frac{1}{3}}\right]
\end{aligned}
$$

$\mathrm{K} / \mathrm{S}$ (dye uptake: 표면염착농도)는 안토시아닌의 최대흡수파장 에서 R (분광반사율) 값을 평균으로 산출하여 Kubelka-Munk식에 의하여 값을 구하였다(Shin \& Park, 2014).

$$
\mathrm{K} / \mathrm{S}=\frac{(1-R)^{2}}{2 R}
$$

$\mathrm{K}$, 염색물의 흡수계수; $\mathrm{S}$, 염색물의 산란계수; $\mathrm{R}$, 분광반사율

\section{3) $\mathrm{pH}$ 변화에 따른 모발 염색 효과}

블루베리 추출액 $15 \mathrm{~mL}$ 에 $\mathrm{pH}$ Meters (Thermo Fisher Scientific, USA)와 $\mathrm{pH}$ 조정제로 $\mathrm{NaOH}$ (Duksan, Korea), $\mathrm{H}_{2} \mathrm{SO}_{4}$ (Duksan)를 사용하여 $\mathrm{pH}$ 3-10 범위로 $\mathrm{pH}$ 를 조정하였다. 각각의 $\mathrm{pH}$ 에서 블루베리 추출액의 최적 염색 조건인 염색 온도 $40^{\circ} \mathrm{C}$, 염 색 시간 $40 \mathrm{~min}$ 으로 염색한 후, 분광측색계로 안토시아닌의 최대 흡수파장에서 $\mathrm{pH}$ 변화에 따른 모발 염색 효과를 측정하였다.

4) 매염 방법에 따른 모발 염색 효과

$0.1 \mathrm{M}$ 농도의 매염제 $\mathrm{FeSO}_{4}, \mathrm{MgSO}_{4}, \mathrm{MnSO}_{4}, \mathrm{CuSO}_{4}$, $\mathrm{AlK}\left(\mathrm{SO}_{4}\right)_{2}, \mathrm{CH}_{3} \mathrm{COOH}, \mathrm{Co}\left(\mathrm{NO}_{3}\right)_{2}, \mathrm{CaCO}_{3}, \mathrm{Na}_{2} \mathrm{CO}_{3}$ (Duksan)을 사용하여 선매염, 동시매염, 후매염을 실시한 후, 블루베리 추출액 의 최적 염색 조건인 염색 온도 $40^{\circ} \mathrm{C}$, 염색 시간 $40 \mathrm{~min}$ 에서 염색 하고 분광측색계로 안토시아닌의 최대흡수파장에서 매염 방법에 따른 모발 염색 효과를 측정하였다. 
(1) 선매염

각각의 매염제 $15 \mathrm{~mL}$ 에 모발시료를 담근 후 상온에서 $30 \mathrm{~min}$ 간 매염 처리한 후 흐르는 물에 수세하고, 자연 건조한 후 염액 $15 \mathrm{~mL}$ 에 모발을 담그고 $40^{\circ} \mathrm{C}, 40 \mathrm{~min}$ 간 염색한 후 흐르는 물에 수세하 여 자연 건조하였다.

(2) 동시매염

염액 $15 \mathrm{~mL}$ 와 각각의 매염제 $15 \mathrm{~mL}$ 를 혼합한 다음 모발시료를 담근 후, $40^{\circ} \mathrm{C}, 40 \mathrm{~min}$ 간 염색한 후 흐르는 물에 수세하고 자연 건 조하였다.

(3) 후매염

염액 $15 \mathrm{~mL}$ 에 모발시료를 담근 후 $40^{\circ} \mathrm{C}$ 에서 $40 \mathrm{~min}$ 간 염색하고 흐르는 물에 수세하여, 자연 건조한 후 각각의 매염제 $15 \mathrm{~mL}$ 에 모 발을 담근 후 상온에서 $30 \mathrm{~min}$ 간 자연 방치한 후 흐르는 물에 수세 하여 자연 건조하였다.

\section{5) 매염제 농도에 따른 모발 염색 효과}

$1 \mathrm{M}$ 농도의 매염제 $\mathrm{FeSO}_{4}, \mathrm{CuSO}_{4}, \mathrm{AlK}\left(\mathrm{SO}_{4}\right)_{2}, \mathrm{Co}\left(\mathrm{NO}_{3}\right)_{2}$ 를 1, $5,10,15,20 \%$ 로 희석하여 선매염을 실시한 후, 블루베리 추출액 의 최적 염색 조건인 염색 온도 $40^{\circ} \mathrm{C}$, 염색 시간 $40 \mathrm{~min}$ 에서 염색 하여 분광측색계로 안토시아닌의 최대흡수파장에서 매염제 농도에 따른 모발 염색 효과를 측정하였다.

\section{6) 세정 견뢰도}

세정 견뢰도는 $\mathrm{KS} \mathrm{K} \mathrm{ISO} \mathrm{105-C01의} \mathrm{세탁} \mathrm{견뢰도} \mathrm{시험} \mathrm{방법을}$ 변형하여 측정하였다(Jeon et al., 2011). 시험 방법은 염색된 모발 시료를 $\mathrm{A}$ 사 컬러전용 샴푸제를 사용하여 물 $500 \mathrm{~mL}$ 에 약 $5 \mathrm{~g}$ 을 희
석하여 $3 \mathrm{~min}$ 간 손으로 세척하고, 수돗물에 좌, 우로 20 회씩 흔들 어 수세하는 방법으로 세정한 다음 자연 건조 후 각각의 모발시료 를 분광측색계로 측정하였다(Jeon et al., 2011).

\section{Results and Discussion}

\section{1. 블루베리 추출액의 흡광도 측정}

블루베리 염액을 희석하여 분광측색계로 400-700 nm 범위에 서 흡광도(absorbance)를 측정한 결과 블루베리 추출물의 안토시아 닌 색소의 최대흡수파장은 $520 \mathrm{~nm}$ 였다. 이때 실험에 사용한 탈색 된 모발시료의 $\mathrm{L}^{*}$ 값은 $17.955, \mathrm{a}^{*}$ 값은 $0.620, \mathrm{~b}^{*}$ 값은 4.893 그리고 $\mathrm{K} / \mathrm{S}$ 값은 20.625 이었다.

\section{2. 염색 온도 및 염색 시간에 따른 모발 염색 효과}

블루베리 염액의 염색 온도 및 염색 시간에 따른 모발 염색 효과는 Table 1 과 같다. 블루베리 추출물의 안토시아닌 색소는 염색 온도와 염색 시간이 증가할수록 $\mathrm{K} / \mathrm{S}$ 값은 증가하고, $\mathrm{L}^{*}$ 값은 감소하는 것으 로 나타났으며, K/S 값은 21.639-58.968로 나타났다. 이 결과는 동 일한 추출법을 사용한 아로니아의 K/S 값인 68.255-76.266 (Kim \& Park, 2014), 블랙베리의 K/S 값인 39.848-61.369 (Shin \& Park, 2014), 포도 껍질의 K/S 값인 25.557-55.726 (Seo \& Park, 2015)보 다는 상대적으로 낮게 나타났으며, 머루의 K/S 값인 15.229-44.519 (Choi \& Park, 2016), 오디의 K/S 값인 11.740-36.700 (Jang \& Park, 2015) 보다는 높은 염착도를 나타냈다. 안토시아닌의 고유 한 색상을 반영하는 $\mathrm{a}^{*}$ 값은 염색 온도 $40^{\circ} \mathrm{C}$, 염색 시간 $20 \mathrm{~min}$ 에

Table 1. Colorimeter values of hair dyed with extracts of blueberry in diverse dyeing temperature and time

\begin{tabular}{|c|c|c|c|c|c|}
\hline Temperature $\left({ }^{\circ} \mathrm{C}\right)$ & Time (min) & $L^{*}$ & $a^{*}$ & $b^{*}$ & $\mathrm{~K} / \mathrm{S}$ \\
\hline \multirow{5}{*}{25} & 10 & 17.126 & 1.956 & 1.080 & 21.639 \\
\hline & 20 & 16.390 & 1.505 & 1.805 & 23.402 \\
\hline & 40 & 12.675 & 1.241 & 0.257 & 34.165 \\
\hline & 60 & 10.130 & 2.475 & -0.438 & 48.178 \\
\hline & 80 & 9.811 & 2.016 & -0.388 & 49.560 \\
\hline \multirow{5}{*}{40} & 10 & 16.962 & 1.521 & 2.186 & 22.273 \\
\hline & 20 & 14.789 & 5.779 & -1.696 & 29.672 \\
\hline & 40 & 10.844 & 4.948 & -0.460 & 47.734 \\
\hline & 60 & 9.650 & 2.842 & -0.166 & 52.570 \\
\hline & 80 & 8.634 & 2.159 & -0.314 & 58.968 \\
\hline \multirow{5}{*}{60} & 10 & 14.810 & 4.871 & -0.564 & 29.158 \\
\hline & 20 & 12.879 & 4.216 & -1.993 & 34.985 \\
\hline & 40 & 9.555 & 3.181 & -1.187 & 52.438 \\
\hline & 60 & 8.968 & 2.561 & -0.412 & 56.264 \\
\hline & 80 & 8.472 & 1.696 & -0.235 & 58.802 \\
\hline
\end{tabular}

L , lightness (0-100); a*, CIE Lab-redness $( \pm a) ; b^{*}$, CIE Lab-yellowness $( \pm b) ; K / S$, dye uptake. 


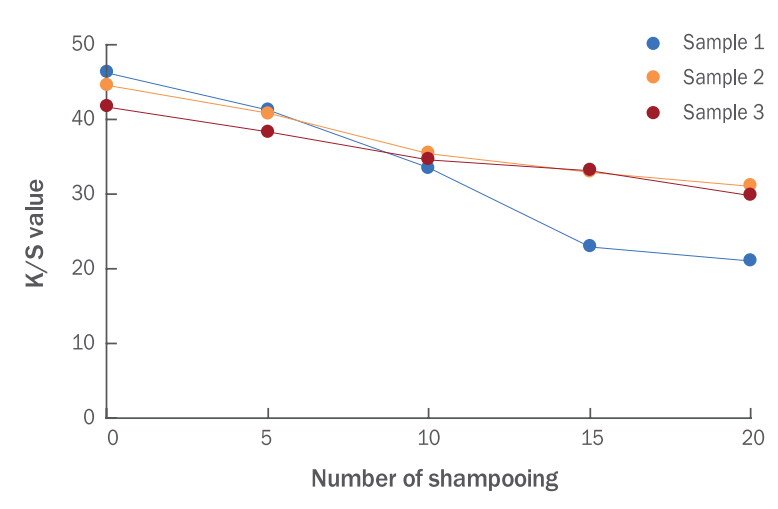

Figure 1. Changes of $\mathrm{K} / \mathrm{S}$ value of dyed hair with extracts from blueberry as washing shampoo.

To confirm the colorfastness of hair samples dyed with blueberry extracts, three samples were washed by shampooing at the indicated number. The absorbance was measured at $520 \mathrm{~nm}$ using a spectrophotometer. The colorfastness to washing was decreased with repeated shampooing. The $\mathrm{K} / \mathrm{S}$ value was in the 46.333-21.098 range, and the K/S difference was 16.911 after washing. $\mathrm{K} / \mathrm{S}$, dye uptake.

서 5.779 로 가장 높게 나타났으나, 염색 시간 $10 \mathrm{~min}$ 과 $20 \mathrm{~min}$ 간 의 $\mathrm{K} / \mathrm{S}$ 값 차이가 7.399로 낮게 나타났다. 그러나 염색 온도 $40^{\circ} \mathrm{C}$, 염색 시간 $40 \mathrm{~min}$ 에서는 염색 시간 $20 \mathrm{~min}$ 과 $40 \mathrm{~min}$ 간의 $\mathrm{K} / \mathrm{S}$ 값 차이가 18.062 로 높게 나타나며, $\mathrm{a}^{*}$ 값이 4.948 로 나타났다. 이 결 과를 바탕으로 염색 시간이 증가함에 따라 $\mathrm{K} / \mathrm{S}$ 값의 증가 폭이 크면 서, 안토시아닌의 고유한 적색이 강한 염색 온도 $40^{\circ} \mathrm{C}$, 염색 시간 40 $\min$ 을 표준 염색 조건으로 결정하고 실험을 진행하였다. 이 결과는 Shin \& Park (2014)의 오디 연구와 일치하였다.

\section{3. $\mathrm{pH}$ 변화에 따른 모발 염색 효과}

블루베리 염액의 $\mathrm{pH}$ 변화에 따른 모발 염색 효과는 Table 2 와 같다. 블루베리의 안토시아닌 색소의 $\mathrm{pH}$ 조성에 따른 색상 변화는
블루베리 원액의 $\mathrm{pH}$ 와 유사한 $\mathrm{pH} 3$ 에서 $\mathrm{a}^{*}$ 값이 4.949 로 가장 높 고, $\mathrm{K} / \mathrm{S}$ 값이 56.156 로 가장 염착도가 높아 밝고 진한 적자색을 나 타냈다. $\mathrm{pH}$ 가 증가함에 따라 $\mathrm{K} / \mathrm{S}$ 값은 낮아지고, 그 결과 $\mathrm{L}^{*}$ 값은 증가하였다. $\mathrm{a}^{*}$ 값이 감소하여 적색이 감소하였으며, $\mathrm{pH}$ 7-10에서 는 안토시아닌 색소의 본래의 색이 퇴색하며 $\mathrm{b}^{*}$ 값이 증가하여 황 색을 띄게 되었다. 이 결과는 Choi \& Park (2016)의 안토시아닌 색소의 $\mathrm{pH}$ 변화에 따른 염색 효과에서의 결과와 일치한다. 이로서 안토시아닌 색소는 $\mathrm{pH}$ 가 색소 안정성에 많은 영향을 미친다는 것을 알 수 있었다. Kim et al. (2008)은 안토시아닌의 색소 안정성 연구 에서 $\mathrm{pH} 4$ 이하의 산성에서는 안토시아닌의 색소 안정성이 유지되 나, $\mathrm{pH} 4$ 이상에서는 급격히 색소 안정성이 파괴된다고 하였다.

\section{4. 매염 방법에 따른 모발 염색 효과}

블루베리 염액의 매염 방법에 따른 모발 염색 효과는 Table 3 과 같다. 실험에 사용한 매염제 가운데 $\mathrm{AlK}\left(\mathrm{SO}_{4}\right)_{2}$ 를 제외한 모든 매염 제에서 $\mathrm{K} / \mathrm{S}$ 값은 선매염이 가장 높게 나타났다. 매염제 중 $\mathrm{FeSO}_{4}$, $\mathrm{MgSO}_{4}, \mathrm{CuSO}_{4}, \mathrm{CaCO}_{3}, \mathrm{Na}_{2} \mathrm{CO}_{3}$ 는 선매염>동시매염>후매염으로 $\mathrm{K} / \mathrm{S}$ 값이 나타났으며, $\mathrm{MnSO}_{4}, \mathrm{CH}_{3} \mathrm{COOH}, \mathrm{Co}\left(\mathrm{NO}_{3}\right)_{2}$ 는 선매염>후 매염>동시매염, $\mathrm{AlK}\left(\mathrm{SO}_{4}\right)_{2}$ 은 후매염>선매염>동시매염으로 $\mathrm{K} / \mathrm{S}$ 값 이 나타났다.

$\mathrm{FeSO}_{4}$ 는 선매염시 진한 적갈색, 후매염시 엷은 적색을 띄는 진 한 갈색, 동시매염시 엷은 적색을 띄는 엷은 갈색을 나타내었다. $\mathrm{MgSO}_{4}$ 과 $\mathrm{MnSO}_{4}$ 는 선매염에서 밝은 적자색을 나타내었고, $\mathrm{CuSO}_{4}$ 는 선매염시 진한 적자색, 후매염시 엷은 보랏빛을 띄는 회색을 나 타내었다. $\mathrm{AlK}\left(\mathrm{SO}_{4}\right)_{2}$ 는 선매염시 밝은 진한 적색, 후매염에서는 엷 은 보라색을 나타내었다. $\mathrm{CH}_{3} \mathrm{COOH}$ 는 모든 매염법에서 밝은 진한 적색이 나타났다. $\mathrm{Co}\left(\mathrm{NO}_{3}\right)_{2}$ 는 선매염에서 엷은 적자색이 나타났으 며, 알칼리성 매염제인 $\mathrm{CaCO}_{3}, \mathrm{Na}_{2} \mathrm{CO}_{3}$ 는 선매염에서는 탁한 적색 이 나타났으나, 후매염시 알칼리성에 의한 안토시아닌 색소의 본래 의 색이 퇴색하여 염색 효과를 기대하기 힘들었다.

Table 2. Colorimeter values of hair dyed with extracts of blueberry in diverse dyeing pH

\begin{tabular}{lcccc}
\hline pH & \multicolumn{1}{c}{ L $^{*}$} & $a^{*}$ & $b^{*}$ & $K / S$ \\
Not pH control dyeing fluid (3.23) & 10.844 & 4.948 & -0.460 & 47.734 \\
pH 3 & 9.574 & 4.949 & -0.626 & 56.156 \\
pH 4 & 9.942 & 2.471 & -0.450 & 49.213 \\
pH 5 & 10.031 & 1.315 & 0.366 & 47.079 \\
pH 6 & 16.681 & 1.134 & 2.047 & 22.394 \\
pH 7 & 16.572 & 0.510 & 2.987 & 22.834 \\
pH 8 & 16.842 & 0.449 & 3.624 & 22.703 \\
pH 9 & 18.539 & -0.134 & 4.863 & 19.694 \\
pH 10 & 24.548 & 0.677 & 7.273 & 11.988 \\
\hline
\end{tabular}

L*, lightness (0-100); a*, CIE Lab-redness ( $\pm a) ; b^{*}$, CIE Lab-yellowness ( $\left.\pm b\right) ; K / S$, dye uptake. 


\section{5. 매염제 농도에 따른 모발 염색 효과}

모발 염색시 다양한 색상을 구현하거나 색소 안정성을 높이기 위해 사용하는 매염제는 중금속을 함유하고 있는 경우가 많다. 이 러한 중금속은 두피를 통하여 흡수되어 머리카락과 손톱 등에 축적 되어(Song, 1979), 문제성 두피 및 확산성 탈모증의 원인이 된다고 보고되었다(Lee et al., 2008). 그러므로 매염제 사용시 최소한의 사용이 필요하다. Song et al. (1999)은 황산구리, 황산제일철, 황 산알루미늄, 주석을 매염제로 사용한 결과 매염 효과가 있다고 보 고하였다.

블루베리 염액의 매염제 농도에 따른 모발 염색 효과는 Table 4 와 같다. 이때 사용한 매염 방법은 Table 3 의 결과에 따라, 대부분 의 매염제에서 $\mathrm{K} / \mathrm{S}$ 값이 가장 높게 나타난 선매염법을 사용하였 다. $\mathrm{FeSO}_{4}$ 는 $1 \%$ 에서 $\mathrm{K} / \mathrm{S}$ 값이 69.665 로 가장 높게 나타났으며 농 도가 증가하여도 $\mathrm{K} / \mathrm{S}$ 값의 차이는 크지 않아, 진한 적갈색을 나타
내는데 매염제는 $1 \%$ 정도의 적은 양으로도 매염 효과가 나타났다. $\mathrm{CuSO}_{4}$ 는 $5,15 \%$ 에서 $\mathrm{K} / \mathrm{S}$ 값이 59.515 로 가장 높게 나타났으며, $5 \%$ 이후 $\mathrm{K} / \mathrm{S}$ 값은 차이가 크지 않아 적자색을 나타내는데 매염제 는 $5 \%$ 면 충분하나, $15 \%$ 에서 $\mathrm{a}^{*}$ 값이 4.239 로 상대적으로 높게 나 타나 진한 적자색을 나타내고자 한다면 매염제 $15 \%$ 가 효과적이었 다. $\mathrm{AlK}\left(\mathrm{SO}_{4}\right)_{2}$ 와 $\mathrm{Co}\left(\mathrm{NO}_{3}\right)_{2}$ 는 $20 \%$ 에서 $\mathrm{K} / \mathrm{S}$ 값이 각각 66.555 와 63.127로 가장 높게 나타나 진한 적색과 적갈색을 나타내었다.

\section{6. 세정 견뢰도}

블루베리 추출물을 이용하여 염색 온도 $40^{\circ} \mathrm{C}$, 염색 시간 $40 \mathrm{~min}$ 에서 염색한 모발시료 3 개를 $\mathrm{A}$ 사 컬러전용 샴푸제를 사용하여 물 $500 \mathrm{~mL}$ 에 약 $5 \mathrm{~g}$ 을 희석하여 $3 \mathrm{~min}$ 간 손으로 세척하고, 수돗물에 좌, 우로 20 회씩 흔들어 수세하는 방법으로 $5,10,15,20$ 회 샴푸한 결과를 Figure 1에 나타내었다. 이때 K/S 값은 46.333-21.098 범위

Table 3. Colorimeter values of hair dyed with extracts of blueberry in diverse mordanting method

\begin{tabular}{|c|c|c|c|c|c|}
\hline Mordant (0.1 M) & Mordanting method & $\mathrm{L}^{*}$ & $a^{*}$ & $b^{*}$ & $\mathrm{~K} / \mathrm{S}$ \\
\hline \multirow{3}{*}{$\mathrm{FeSO}_{4}$} & Pre-mordanting & 7.539 & 1.220 & -0.458 & 66.133 \\
\hline & Simultaneous mordanting & 9.877 & 0.888 & 0.306 & 48.060 \\
\hline & Post-mordanting & 9.964 & 0.916 & 0.057 & 46.752 \\
\hline \multirow{3}{*}{$\mathrm{MgSO}_{4}$} & Pre-mordanting & 10.306 & 2.948 & -0.052 & 48.626 \\
\hline & Simultaneous mordanting & 10.497 & 2.126 & 0.150 & 45.613 \\
\hline & Post-mordanting & 10.870 & 2.439 & 0.190 & 43.955 \\
\hline \multirow{3}{*}{$\mathrm{MnSO}_{4}$} & Pre-mordanting & 9.937 & 3.993 & -1.019 & 51.282 \\
\hline & Simultaneous mordanting & 12.621 & 1.497 & 1.073 & 34.997 \\
\hline & Post-mordanting & 12.063 & 2.439 & 0.740 & 38.214 \\
\hline \multirow{3}{*}{$\mathrm{CuSO}_{4}$} & Pre-mordanting & 8.782 & 3.018 & -0.971 & 58.674 \\
\hline & Simultaneous mordanting & 9.451 & 1.887 & -0.282 & 51.926 \\
\hline & Post-mordanting & 10.634 & 0.823 & -0.807 & 42.499 \\
\hline \multirow{3}{*}{$\mathrm{AlK}\left(\mathrm{SO}_{4}\right)_{2}$} & Pre-mordanting & 11.458 & 8.786 & -1.254 & 49.195 \\
\hline & Simultaneous mordanting & 9.920 & 1.922 & 0.092 & 48.626 \\
\hline & Post-mordanting & 9.640 & 2.997 & -1.764 & 50.654 \\
\hline \multirow{3}{*}{$\mathrm{CH}_{3} \mathrm{COOH}$} & Pre-mordanting & 7.723 & 3.434 & -0.412 & 68.298 \\
\hline & Simultaneous mordanting & 11.841 & 6.412 & 0.073 & 44.915 \\
\hline & Post-mordanting & 11.424 & 6.697 & -0.291 & 47.397 \\
\hline \multirow{3}{*}{$\mathrm{Co}\left(\mathrm{NO}_{3}\right)_{2}$} & Pre-mordanting & 8.660 & 3.336 & -0.283 & 60.030 \\
\hline & Simultaneous mordanting & 13.080 & 2.344 & 0.070 & 33.774 \\
\hline & Post-mordanting & 11.641 & 3.202 & 0.132 & 41.053 \\
\hline \multirow{3}{*}{$\mathrm{CaCO}_{3}$} & Pre-mordanting & 9.308 & 3.296 & -0.561 & 55.398 \\
\hline & Simultaneous mordanting & 13.884 & 0.010 & 1.299 & 28.933 \\
\hline & Post-mordanting & 14.045 & 0.977 & 0.624 & 28.726 \\
\hline \multirow{3}{*}{$\mathrm{Na}_{2} \mathrm{CO}_{3}$} & Pre-mordanting & 10.143 & 3.356 & -0.440 & 49.679 \\
\hline & Simultaneous mordanting & 13.015 & 0.571 & 3.287 & 34.757 \\
\hline & Post-mordanting & 13.528 & -0.178 & 2.657 & 31.076 \\
\hline
\end{tabular}

$L^{*}$, lightness (0-100); a*, CIE Lab-redness $( \pm a) ; b^{*}$, CIE Lab-yellowness $( \pm b) ; K / S$, dye uptake. 
에서 나타났으며, 세정 횟수가 증가함에 따라 $\mathrm{K} / \mathrm{S}$ 값은 평균 16.911 감소하였다. 이 결과는 오디 추출물의 8.342 보다는 크게 나타났으 며, 아로니아 추출물의 17.210 , 머루 추출물의 22.272 , 포도껍질 추 출물의 31.917, 블랙베리 추출물에서 47.406 보다는 낮게 나타났다 (Choi \& Park, 2016; Seo \& Park, 2015). 이 결과를 통해 블루베리 추출물을 모발 염료로 사용하려면 매염제의 사용이 필요하다고 판단 되었다.

\section{Conclusion}

블루베리 추출물의 안토시아닌 최대흡수파장은 $520 \mathrm{~nm}$ 로 나타 났다. 모발 염색시 염색 온도와 염색 시간이 증가할수록 $\mathrm{K} / \mathrm{S}$ 값이 증가하고, $\mathrm{L}^{*}$ 값이 감소하였다. 이때 $\mathrm{K} / \mathrm{S}$ 값은 21.639-58.968이었 다. $\mathrm{K} / \mathrm{S}$ 값의 차가 크면서, 안토시아닌의 고유한 색상을 반영하는 $\mathrm{a}^{*}$ 값이 높은 염색 온도 $40^{\circ} \mathrm{C}$, 염색 시간 $40 \mathrm{~min}$ 을 블루베리 추출 물의 표준 염색 조건으로 설정하였다. 안토시아닌 염제는 $\mathrm{pH}$ 에 민 감하게 반응하고 $\mathrm{pH}$ 가 증가함에 따라 염착성은 급격히 감소하였다. 산성에서는 $\mathrm{a}^{*}$ 값이 증가하고, 알칼리에서는 $\mathrm{b}^{*}$ 값이 증가하는 것
으로 나타났다. 블루베리 염액의 매염 방법에 따른 $\mathrm{K} / \mathrm{S}$ 값 변화는 선매염이 가장 높게 나타났다. 매염제 중 $\mathrm{FeSO}_{4}, \mathrm{MgSO}_{4}, \mathrm{CuSO}_{4}$, $\mathrm{CaCO}_{3}, \mathrm{Na}_{2} \mathrm{CO}_{3}$ 는 선매염>동시매염>후매염으로 $\mathrm{K} / \mathrm{S}$ 값이 나타났 으며, $\mathrm{MnSO}_{4}, \mathrm{CH}_{3} \mathrm{COOH}, \mathrm{Co}\left(\mathrm{NO}_{3}\right)_{2}$ 는 선매염〉후매염>동시매염, $\mathrm{AlK}\left(\mathrm{SO}_{4}\right)_{2}$ 은 후매염>선매염>동시매염으로 $\mathrm{K} / \mathrm{S}$ 값이 나타났다. 매 염제 농도에 따른 따른 $\mathrm{K} / \mathrm{S}$ 값 변화는 $\mathrm{FeSO}_{4}$ 는 $1 \%$ 에서 69.665 , $\mathrm{CuSO}_{4}$ 는 $5,15 \%$ 에서 $59.515, \mathrm{AlK}\left(\mathrm{SO}_{4}\right)_{2}$ 와 $\mathrm{Co}\left(\mathrm{NO}_{3}\right)_{2}$ 는 $20 \%$ 에서 각 각 66.555 와 63.127 로 가장 높게 나타났다. 컬러 전용 샴푸제를 사용 하여 세정방법으로 0-20회 반복 세정시 염착량은 46.333-21.098로 세정 후 $\mathrm{K} / \mathrm{S}$ 값 차는 평균 16.911 로 나타났다. 이상의 연구 결과는 블 루베리 추출물의 안토시아닌 색소는 인간의 모발에 적용 가능한 천연 염모제로서의 가능성을 가지고 있으며, 매염제 사용시 다양한 색상 구현 및 염착도를 향상시킬 수 있어 천연 다색성 염료로 사용이 가능 하리라 사료된다. 그러나 향후 안토시아닌 색소의 염색 재현성과 안 정성을 확보하기 위한 연구가 체계적으로 진행되어야 할 것이다.

\section{Acknowledgements}

이 논문은 2016년도 남부대학교 학술연구비의 지원을 받아 연 구되었음.

Table 4. Colorimeter values of hair dyed with extracts of blueberry in diverse mordanting concentration

\begin{tabular}{|c|c|c|c|c|c|}
\hline Mordant (1 M) & Mordant concentration & $L^{*}$ & $a^{*}$ & $b^{*}$ & $\mathrm{~K} / \mathrm{S}$ \\
\hline \multirow{5}{*}{$\mathrm{FeSO}_{4}$} & $1 \%$ & 7.154 & 1.245 & -0.450 & 69.665 \\
\hline & $5 \%$ & 7.278 & 1.150 & -0.486 & 67.634 \\
\hline & $10 \%$ & 7.539 & 1.220 & -0.458 & 66.133 \\
\hline & $15 \%$ & 7.827 & 1.265 & -0.385 & 63.319 \\
\hline & $20 \%$ & 7.279 & 1.061 & -0.653 & 68.075 \\
\hline \multirow{5}{*}{$\mathrm{CuSO}_{4}$} & $1 \%$ & 9.602 & 3.731 & -1.054 & 53.114 \\
\hline & $5 \%$ & 8.752 & 3.701 & -1.150 & 59.515 \\
\hline & $10 \%$ & 8.782 & 3.018 & -0.971 & 58.674 \\
\hline & $15 \%$ & 8.758 & 4.239 & -1.584 & 59.515 \\
\hline & $20 \%$ & 8.843 & 3.877 & -1.186 & 59.008 \\
\hline \multirow{5}{*}{$\mathrm{AlK}\left(\mathrm{SO}_{4}\right)_{2}$} & $1 \%$ & 9.611 & 4.119 & 0.009 & 55.683 \\
\hline & $5 \%$ & 10.777 & 7.452 & -0.593 & 51.914 \\
\hline & $10 \%$ & 11.458 & 8.786 & -1.254 & 49.195 \\
\hline & $15 \%$ & 10.423 & 7.051 & -0.863 & 53.804 \\
\hline & $20 \%$ & 7.846 & 3.115 & -0.407 & 66.555 \\
\hline \multirow{5}{*}{$\mathrm{Co}\left(\mathrm{NO}_{3}\right)_{2}$} & $1 \%$ & 9.135 & 3.570 & 0.165 & 57.696 \\
\hline & $5 \%$ & 8.628 & 3.066 & 0.040 & 60.379 \\
\hline & $10 \%$ & 8.660 & 3.336 & -0.283 & 60.030 \\
\hline & $15 \%$ & 8.755 & 3.130 & -0.287 & 59.515 \\
\hline & $20 \%$ & 8.360 & 3.335 & -0.199 & 63.127 \\
\hline
\end{tabular}

$\mathrm{L}^{*}$, lightness (0-100); a*, CIE Lab-redness ( $\left.\pm a\right) ; b^{*}$, CIE Lab-yellowness $( \pm b) ; \mathrm{K} / \mathrm{S}$, dye uptake. 


\section{References}

Ali S, Hussain T, Nawaz R. Optimization of alkaline extraction of natural dye from henna leaves and its dyeing on cotton by exhaust method. Journal of Cleaner Production, 17: 61-66, 2009.

Chae HO, Na HY, Na MS. Mechanical characteristics of hair by processing temperature and time on treated coloring hair. Journal of the Korean Society of Cosmetology, 16: 327-332, 2010.

Choi MH, Shin HJ. Anti-oxidative and anti-melnogenesis effects of buleberry extract. Asian Journal of Beauty and Cosmetology, 13: 261-266, 2015

Choi YY, Park $\mathrm{CH}$. Hair dyeing properties using extracts of wild grape (Vitis coignetiae). Asian Journal of Beauty and Cosmetology, 14: 329-338, 2016.

Jang AS, Park $\mathrm{CH}$. A study on the hair dyeing and colorfastness using extracts of mulberry. Asian Journal of Beauty and Cosmetology, 13: 237-242, 2015.

Jang M, Cai L, Udeani GO, Slowing KV, Thomas CF, Beecher CW, Fong $\mathrm{HH}$, Farnsworth NR, Kinghorn AD, Mehta RG, et al. Cancer chemopreventive activity of resveratrol, a natural product derived from grapes. Science, 275: 218-220, 1997.

Jeon AR, Kim SY, Choi HJ, Na MS. Human hair dyed and colorfastness of hot water extract from gallnut. Journal of the Korean Society of Cosmetology, 17: 87-93, 2011.

Jeong $\mathrm{CH}$, Choi SG, Heo HJ. Analysis of nutritional compositions and antioxidative activities of Korean commercial blueberry and raspberry. Journal of the Korean Society of Food Science and Nutrition, 37: 1375-1381, 2008.

Jung J, Park J, Kim T. Coloration of cotton fabrics with tannins of persimmon extracts by heating process. Textile Coloration and Finishing, 20: 25-30, 2008.

Kim JY, Park CH. Hair dyeing properties using extracts of Aronia melancocarpa. Asian Journal of Beauty and Cosmetology, 12: 663-668, 2014.

Kim SY, Ko KO, Lee YS, Kim HS, Kim YH. Extraction efficiency and stability of anthocyanin pigments in black soybean seed coat. Korean Journal of Crop Science, 53: 84-88, 2008.

Lee GY, Chang BS. Ultrstructural changes of hair cuticle layer treated with permanent dye. Journal of Investigative Cosmetology, 7: 267-271, 2011.

Lee JR, Park CH. Natural hair dyeing using a black soybean seed coat. Journal of Investigative Cosmetology, 8: 127-134,
2012.

Lee JS, Son JY, Eo SH. A study on toxic heavy metal by analysis of alopeciec hair. Journal of the Korean Society of Cosmetology, 14: 857-865, 2008.

Lee SN, Kang KJ. The effect of blueberry on ROS accumulation and cell death in human normal breast epithelial (MCF10A) and breast cancer (MCF7) cells. The Korean Journal of Food and Nutrition, 21: 416-424, 2008.

Lim HJ, Lee HJ, Lim MH. Antioxidant activity of acaiberry, blueberry, corni, and mulberry. Asian Journal of Beauty and Cosmetology, 13: 445-452, 2015.

Martineau LC, Couture A, Spoor D, Benhaddou-Andaloussi A, Harris C, Meddah B, Leduc C, Burt A, Vuong T, Mai Le P, et al. Anti-diabetic properties of the Canadian lowbush blueberry Vaccinium angustifolium Ait. Phytomedicine, 13: 612-623, 2006.

Park AY, Song WS, Kim IY. Effect of tannin mordanting on gromwell-dyed silk fabric. Textile Coloration and Finishing, 20: 51-62, 2008.

Seo ES, Ryu GC. An effect of visual acuity protection by natural pigment (anthocyanine) extracted from fermented purple sweet potato. Journal of Korean Ophthalmic Optics Society, 17: 395-401, 2012.

Seo JC, Park CH. A study on the hair dyeing properties by using extracts of grape skin. Asian Journal of Beauty and Cosmetology, 13: 689-694, 2015.

Shin HN, Park CH. A study on the hair dyeing properties by using extracts of Rubus fruticosus. Journal of the Korean Society of Cosmetology, 20: 30-35, 2014.

Song DB. Trace metal contents in human hair of Korean. Journal of Preventive Medicine and Public Health, 12: 79-87, 1979.

Song HN, Park MS, Youn HS, Park SJ, Hogstrand C. Nutritional compositions and antioxidative activities of two blueberry varieties cultivated in South Korea. Korean Journal of Food Preservation, 21: 790-798, 2014.

Song KH, Kim BH, Choi YS, Byun SY. Study on natural dyeing using the Elm-bark. The Journal of Natural Sciences, 11: 143-150, 1999.

Su MS, Chien PJ. Antioxidant activity, anthocyanins, and phenolics of rabbiteye blueberry (Vaccinium ashei) fluid products as affected by fermentation. Food Chemistry, 104: 182-187, 2007.

Westwood MN. Temperate-zone pomology: physiology and culture. Timber Press, Portland, pp100-101, 1993. 


\section{국문초록}

\section{블루베리 추출물의 모발 염색 및 견뢰도 연구}

서은성, 박철호*

남부대학교 향장미용학과, 광주, 한국

목적: 본 연구는 블루베리 추출물의 안토시아닌 색소를 이용한 모발의 천연 염색 가능성을 알아보고자 하였다. 방법: 블루 베리 추출물의 안토시아닌 최대흡수파장에서 염색 온도, 염색 시간 및 $\mathrm{pH}$ 를 변화시켜가며 염착도와 색 변화를 관찰하였으 며, 몇 가지 매염제를 사용하여 매염 방법 및 매염제 농도에 따른 매염 효과와 세정 견뢰도를 관찰하였다. 결과: 블루베리 추출물의 안토시아닌 최대흡수파장은 $520 \mathrm{~nm}$ 로 나타났다. 모발 염색시 염색 온도와 염색 시간이 증가할수록 염착도(K/S) 가 증가하고, 명도(L")가 감소하였다. 이때 염착도는 21.639-58.968였다. 염착도 차가 크면서, 안토시아닌의 고유한 색상 을 반영하는 적색도 $\left(\mathrm{a}^{*}\right)$ 가 큰 염색 온도 $40^{\circ} \mathrm{C}$, 염색 시간 $40 \mathrm{~min}$ 을 블루베리 추출물의 표준 염색 조건으로 설정하였다. 안 토시아닌 염제가 $\mathrm{pH}$ 에 특히 민감하게 반응하고 대부분 $\mathrm{pH}$ 가 증가함에 따라 염착성은 급격히 감소하였다. 산성에서는 적 색도가 증가하고, 알칼리에서는 황색도(b)가 증가하는 것으로 나타났다. 모발 염색시 매염 방법(선매염, 동시매염, 후매 염)에 따른 염착량 변화는, 매염제 중 $\mathrm{FeSO}_{4}, \mathrm{MgSO}_{4}, \mathrm{MnSO}_{4}, \mathrm{CuSO}_{4}, \mathrm{CH}_{3} \mathrm{COOH}, \mathrm{Co}\left(\mathrm{NO}_{3}\right)_{2}, \mathrm{CaCO}_{3}, \mathrm{Na}_{2} \mathrm{CO}_{3}$ 는 선매 염, $\mathrm{AlK}\left(\mathrm{SO}_{4}\right)_{2}$ 은 후매염이 효과적으로 나타났다. 매염제 농도에 따른 염착도 변화는 $\mathrm{FeSO}_{4}$ 는 $1 \%$ 에서 $69.665, \mathrm{CuSO}_{4}$ 는 $5,15 \%$ 에서 $59.515, \mathrm{AlK}\left(\mathrm{SO}_{4}\right)_{2}$ 와 $\mathrm{Co}\left(\mathrm{NO}_{3}\right)_{2}$ 는 $20 \%$ 에서 각각 66.555 와 63.127 로 가장 높게 나타났다. 컬러 전용 샴푸제 를 사용하여 0-20회 반복 세정시 염착량은 46.333-21.098로 세정 후 염착량 차는 평균 16.911로 나타났다. 결론: 이상 의 연구 결과를 통해 블루베리 추출물의 안토시아닌 색소는 인간의 모발에 적용 가능한 천연 다색성 염료로 사용이 가능하 리라 사료된다.

핵심어: 블루베리, 염색, 안토시아닌, 매염제, 세정 견뢰도

이 논문은 2016년도 남부대학교 학술연구비의 지원을 받아 연구되었음.

\section{참고문헌}

김선영, 고광오, 이영상, 김희선, 김용호. 검정콩 종피 안토시아닌의 적정 추출 효율 및 안정성. 한국작물학회지, $53:$ 8488, 2008.

김주영, 박철호. 아로니아(Aronia melancocarpa) 추출물을 이용한 모발의 염색 특성. 아시안뷰티화장품학술지, 12: 663668, 2014.

박아영, 송화순, 김인영. 견직물의 자초 염색 시 합성탄닌의 매염 효과. 한국염색가공학회지, 20: 51-62, 2008.

서은선, 유근창. 발효 자색고구마 추출 천연색소(anthocyanine)에 의한 시력보호 효과. 한국안광학회지, 17: 395-401, 2012. 서종철, 박철호. 포도껍질 추출물을 이용한 모발의 염색 특성. 아시안뷰티화장품학술지, 13: 689-694, 2015.

송경현, 김병희, 최유석, 변순영. 느릅나무 껍질에 의한 천연염색에 관한 연구. 자연과학논문집, $11: 143-150,1999$.

송동빈. 한국인(韓國人) 모발중(毛髮中)의 미량중금속(微量重金屬) 함량(含量)에 관(關)한 연구(研究): 일부(一部) 대도시(大都

市)와 농촌(農村)을 중심(中心)으로. 예방의학회지, 12: 79-87, 1979.

송효남, 박명수, 윤호식, 박성진, 호그스트랜드 크리스터. 국내산 두 품종 블루베리의 영양성분 및 항산화 활성 비교. 한국식품 저장유통학회지, 21: 790-798, 2014.

신화남, 박철호. 블랙베리(Rubus fruticosus) 추출물을 이용한 모발의 염색특성. 한국미용학회지, 20: 30-35, 2014. 이귀영, 장병수. 영구염색제로 처리한 모발 큐티클층의 미세구조적인 변화. 대한미용학회지, 7: 267-271, 2011. 
이세나, 강금지. 블루베리가 정상유선세포와 유방암세포의 ROS 축적과 세포사멸에 미치는 영향. 한국식품영양학회지, $21:$ 416-424, 2008.

이재숙, 손지연, 어숙희. 탈모인의 모발분석을 통한 연령별 중금속 오염도 비교. 한국미용학회지, 14: 857-865, 2008. 이정례, 박철호. 검정콩 종피를 이용한 모발의 천연염색. 대한미용학회지, 8: 127-134, 2012.

임현지, 이해진, 임미혜. 아사이베리, 블루베리, 산수유, 오디 에탄올 추출물의 항산화 활성도 비교 분석. 아시안뷰티화장품학 술지, 13: 445-452, 2015.

장애선, 박철호. 오디(Mulberry) 추출물의 모발 염색 및 견뢰도 연구. 아시안뷰티화장품학술지, 13: 237-242, 2015.

전아름, 김수영, 최희진, 나명석. 오배자(Gallnut) 열수 추출물의 모발염색 및 염색견뢰도. 한국미용학회지, 17: 87-93, 2011. 정종석, 박지선, 김태경. 감 탄닌 추출물의 열 발색공정에 의한 면직물 염색. 한국염색가공학회지, 20: 25-30, 2008.

정창호, 최성길, 허호진. 국내 시판 블루베리와 라즈베리의 영양성분 분석 및 항산화 활성. 한국식품영양과학회지, $37: 1375-$ 1381, 2008.

채희옥, 나해윤, 나명석. 염색시술시 온도와 방치시간에 따른 모발의 역학적 특성. 한국미용학회지, 16: 327-332, 2010.

최문희, 신현재. 국산 블루베리 착즙액의 항산화 활성 및 멜라닌생성 저해효과. 아시안뷰티화장품학술지, 13: 261-266, 2015. 최윤영, 박철호. 머루(Vitis coignetiae) 추출물을 이용한 모발 염색 특성. 아시안뷰티화장품학술지, 14: 329-338, 2016. 


\section{中文摘要}

\section{蓝莓提取物的染发和色牢度研究}

徐銀晟, 朴哲浩*

南部大学香妆美容学科, 光州, 韩国

目的: 探讨蓝莓提取物的花色苷色素（anthocyanin）作为天然染发剂的可行性。方法: 在蓝莓提取物的花色苷色素的 最大吸收波长下，根据染色温度、时间以及pH的变化，观察染色量和颜色变化。采用几种媒染剂，根据不同媒染方法 和媒染剂浓度, 观察其媒染效果和洗色牢度。结果: 蓝莓提取物的花色苷色素的最大吸收波长为520 nm。染发时, 随 着染色温度和时间的增加, 染色量 (K/S) 增加, 而亮度 ( $\left.L^{*}\right)$ 下降。这时, 染色量为21.639-58.968。蓝莓提取物的 标准染色条件设定为温度 $40^{\circ} \mathrm{C}$, 染色时间 $40 \mathrm{~min}$ 。在这种条件下, 染色量差距较大以及反映花色苷色素固有颜色的红 度 $\left(a^{*}\right)$ 值较大。花色苷色素媒染剂对 $\mathrm{pH}$ 值特别敏感, 大部分随着 $\mathrm{pH}$ 值的增加, 染色性急速降低。在酸性条件下, 红度 ( $a^{*}$ ) 增加; 在碱性条件下, 黄度 ( $\left.b^{*}\right)$ 增加。染发时, 根据媒染方法（预媒染、同时媒染、后媒染）染色量 产生变化, 当媒染剂中 $\mathrm{FeSO}_{4} 、 \mathrm{MgSO}_{4} 、 \mathrm{MnSO}_{4} 、 \mathrm{CuSO}_{4} 、 \mathrm{CH}_{3} \mathrm{COOH} 、 \mathrm{Co}\left(\mathrm{NO}_{3}\right)_{2} 、 \mathrm{CaCO}_{3} 、 \mathrm{Na}_{2} \mathrm{CO}_{3}$ 等被选为预媒 染， AlK $\left(\mathrm{SO}_{4}\right)_{2}$ 被选为后媒染时，染色量的变化具有显著效果。根据媒染剂的浓度，染色量的变化分别为69.665（1\% $\left.\mathrm{FeSO}_{4}\right) ， 59.515\left(5 、 15 \% \mathrm{CuSO}_{4}\right) ， 66.555\left(20 \% \mathrm{AlK}\left(\mathrm{SO}_{4}\right)_{2}\right) ， 63.127\left(20 \% \mathrm{Co}\left(\mathrm{NO}_{3}\right)_{2}\right)$ ，其中 $20 \% \mathrm{AlK}\left(\mathrm{SO}_{4}\right)_{2}$ 和 $20 \% \mathrm{Co}\left(\mathrm{NO}_{3}\right)_{2}$ 的染色量的变化最高。利用专用洗发水反复清洗0-20次后, 其染色量为46.333-21.098, 清洗后, 平均染 色量差为 16.911 。结论: 从以上的研究结果中得出, 蓝莓提取物的花色苷色素可以作为天然多色性染料使用。

关键词: 蓝莓, 染色, 花色苷色素, 媒染剂, 洗色牢度 